JSACE $2 / 27$

Architect Familiarity and Perceptions Surrounding Sustainable Design, LEED, and Engineered Wood Products in Arkansas

Received

2020/01/17

Accepted after revision

2020/09/16

\section{Architect Familiarity and Perceptions Surrounding Sustainable Design, LEED, and Engineered Wood Products in Arkansas}

\section{Gabrielle Sherman}

College of Forestry, Agriculture and Natural Resources, University of Arkansas at Monticello; Monticello, AR 71656, USA

\section{Tamara Walkingstick}

University of Arkansas Cooperative Extension service, University of Arkansas Division of Agriculture, Little Rock, AR 72204, USA

\section{Kenneth Wallen, Matthew Pelkki*}

College of Forestry, Agriculture and Natural Resources, University of Arkansas at Monticello; Monticello, AR 71656, USA

*Corresponding author: pelkkim@uamont.edu

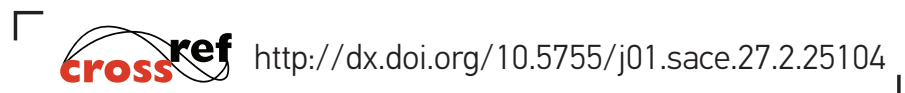

The sustainable building design movement has gained momentum within the United States in recent years. This has led to a proliferation of green building certification programs like Leadership in Energy and Environmental Design (LEED) and the development of engineered wood products (EWP) like cross laminated timber (CLT). Often, architects serve as the conduit between green building construction material and their use in construction. There is need to investigate the perceptions and practices of architects on the topic of green building certification and EWPs. In partnership with the American Institute of Architects (AIA), this study surveyed registered architects practicing in Arkansas to a) examine interest in and application of LEED certification and b) beliefs related to sustainability, affordability, and availability of EWPs. Results suggest a majority of architects surveyed have interest in the LEED program and have previously earned LEEDcertification for a building design. Respondents rated the importance of improving human health and wellbeing as especially high but appear to doubt the ability of EWP to contribute to sustainable design. Analysis revealed that CLT use is significantly lower than that of more typical EWPs such as plywood panels and glue laminated timber. Architects also indicated that the affordability and availability of modern EWP represent significant barriers to their utilization within the state. To increase the rate of sustainable development, it will be necessary to highlight benefits to human and environmental health and generate interest amongst architectural clientele.

Keywords: cross laminated timber, building design, green building certification, mass timbers. 
Sustainability is a hallmark of community planning and development, and public policy, with human-environmental benefits possible through conscientious, environmentally-friendly design choices (Ortiz, Castells, and Sonnemann 2009). Efforts to institutionalize pathways to such choices - e.g., those that guide building construction materials - have led to organizations like the U.S. Green Building Council (USGBC) and the Leadership in Energy and Environmental Design (LEED) criteria. Building construction, in addition to maintenance and operation, account for one-third of global energy use, with roughly $11 \%$ of energy sector emissions originating from the construction industry (Jain, Mital, and Syal 2013; UN IEA 2017). Engineered wood products (EWPs) offer a structural material alternative to steel and concrete construction that can mitigate energy consumption from buildings. In the case of building construction with EWPs or other sustainable materials, the choice to consider or pursue sustainable design and materials is often initialized early in the process by a client or architect. Regarding architects, few studies assess this groups familiarity with, use of, and opinions on sustainable design, LEED, and EWPs, particularly in regions with established forest-products sectors and developing EWP markets. As such, this research examines perceptions of sustainable design, LEED certification, and EWPs among architects practicing in Arkansas.

\section{LEED Certification and Sustainability goals}

The LEED certification systems is a widely recognized and implemented framework for green building design and has evolved over the years to accommodate a growing number of environmental concerns (Matisoff, Noonan, and Mazzolini, 2014; Amiri, Ottelin, and Sovari 2019). Its criterion of sustainability for both old and new construction is comparable to that of other international green building rating systems, such as the UK-based Building Research Establishment Environmental Assessment Method (BREEAM) and Japan's Comprehensive Assessment System for Building Environmental Efficiency (CASBEE) (Ahmed, Hasan, and Mallick, 2018). Whether the evaluation is made through a credit-earning system or benchmark assessment, certification for the majority of green building systems is awarded to construction surpassing some set threshold of ecological efficacy and energy performance (Ahmed, Hasan, and Mallick, 2018).

Within LEED, certification is tiered based on the number of points awarded, with four levels of compliance available: certified, silver, gold, and platinum. Earlier iterations tended to emphasize over-simplified denominations of material sustainability based on single-attribute criteria such as recyclability (USGBC 2019a). A review of LEED buildings in New York found that only buildings of the gold tier and higher produced statistically significant reductions in energy consumption (Scofield 2013). Meanwhile, findings surrounding the energy saving potential of occupied LEED certified buildings reveal that on average, commercial LEED buildings of medium energy use yield energy savings of $19-39 \%$ as compared to equivalent non-LEED counterparts, depending on factors such as age and climate (Newsham, Mancini, and Birt 2009). However, this trend alone does not fully reveal the reality of energy use in LEED buildings, as energy use rates have been found to vary widely amongst individual buildings, and, in fact, $28-35 \%$ of LEED certified buildings were found to use more energy per unit floor area than non-LEED buildings (Newsham, Mancini, and Birt 2009). Amiri and others (2019) found that the energy efficiency of buildings with lower levels of LEED certification was questionable, especially at the "certified" level.

In response to these shortcomings, a new version of the system, known as LEED v4, was introduced (Scofield 2013). Currently, LEED specifies six targeted credit categories through which up to 100 certification points are awarded. In total, they include location and transport, sustainable sites, water efficiency, energy and atmosphere, material and resources, and indoor environmental quality (USGBC 2019a). Ten additional points, known as Innovation and Regional Priority credits, may be awarded to a project based on its ability to address local, specific environmental concerns (USGBC 2019b). By adhering to LEED's accreditation guidelines and requirements within these
Introduction

\begin{tabular}{l}
\hline Literature \\
Review of \\
Contextual \\
and \\
Conceptual \\
Foundations
\end{tabular}


credit categories, buildings can meet the sustainability goals (USGBC 2019a). Sustainability goals, referred to as Impact Categories, were developed as means of addressing the question of what a LEED building should accomplish (USGBC 2019b). In total, there are seven categories, each with its own set of indicators of compliance (Table 1).

\begin{tabular}{|c|c|c|}
\hline \multirow{8}{*}{$\begin{array}{r}\text { The seven LEED } \\
\text { Impact Categories } \\
\text { with corresponding } \\
\text { descriptions }\end{array}$} & LEED v4 Impact Category & Description \\
\hline & $\begin{array}{l}\text { Reverse Contribution to Global Climate } \\
\text { Change }\end{array}$ & $\begin{array}{l}\text { Reduce } \mathrm{CO}_{2} \text { emissions associated with building opera- } \\
\text { tions, transportation, material use, water consumption, } \\
\text { and energy utilization }\end{array}$ \\
\hline & $\begin{array}{l}\text { Enhance Individual Human Health and } \\
\text { Well-Being }\end{array}$ & $\begin{array}{l}\text { Improve comfort of building occupants and reduce expo- } \\
\text { sure to harmful element }\end{array}$ \\
\hline & Protect and Restore Water Resources & $\begin{array}{l}\text { Promote water conservation and water quality preserva- } \\
\text { tion. Preserve natural hydrological cycles }\end{array}$ \\
\hline & $\begin{array}{l}\text { Protect, Enhance and Restore Biodiversity and } \\
\text { Ecosystem Services }\end{array}$ & $\begin{array}{l}\text { Improve habitat conservation opportunities, ecosystem } \\
\text { services, and species diversity on a local and global level }\end{array}$ \\
\hline & $\begin{array}{l}\text { Promote Sustainable and Regenerative } \\
\text { Material Resource Cycles }\end{array}$ & $\begin{array}{l}\text { Reduce negative environmental impacts produced by } \\
\text { raw material extraction through renewable material } \\
\text { life-cycles }\end{array}$ \\
\hline & Build a Greener Economy & $\begin{array}{l}\text { Raise the value of green buildings and support green } \\
\text { industries through financial incentives }\end{array}$ \\
\hline & $\begin{array}{l}\text { Enhance Social Equity, Environmental Justice, } \\
\text { Community Health and Quality of Life }\end{array}$ & $\begin{array}{l}\text { Create a strong sense of place and resilient living } \\
\text { communities. Promote human rights and environmental } \\
\text { justice }\end{array}$ \\
\hline
\end{tabular}

\section{Engineered Wood Products}

If sustainability is to be given a central position in community planning and development, a potential route to address traditional building design shortcomings is via emergent engineered wood products (EWPs). Engineered wood products provide performance and cost improvements over traditional sawn lumber (Van de Lindt et al. 2010). Cross-laminated timbers (CLT) are a rapidly emerging structural EWPs, and is an alternative to steel and concrete, due to their seismic resistance, elasticity, structural strength, and dimensional stability (Van de Lindt et al. 2010; Ritter, Skog, and Bergman 2011). The environmental benefits of CLT include improved use of natural resources, carbon storage, and ecosystem improvement (Ritter, Skog, and Bergman 2011).

\section{Sustainable Design and Architect Perspectives}

Architects play a key role in the promotion sustainable design frameworks like LEED, particularly those that can increase sustainability and the use of forest products that benefit economies and ecosystems (O'Connor et al. 2004). Furthermore, the fact that LEED participation is voluntary on the part of architects and their clientele stresses that from interest, to design, to construction, the success of LEED is partially dependent on cognitive and experiential elements like attitudes, interests, experiences, and familiarity. As such, this research builds on the empirical basis of previous assessments of wood-products sector stakeholders and architects (Franzini, Toivonen, and Toppinen 2018; Mat'ová and Kaputa 2018) alongside a theoretical framework informed by attitude research and volitional behavior, e.g., the theory of planned behavior (TPB) (Ajzen 1991; Bysheim and Nyrud 2009), a conceptualization of direct experience (Heberlein 2012), and past work on familiarity (Hammitt 1979; Peterson and Vaske 2017; Oku and Fukamachi 2006). 


\section{Attitudes}

Attitudes represent an indispensable concept to assess an individual's positive-to-negative evaluation of a phenomenon, for example, a stakeholder's evaluation of local timber extraction (Allport 1935; Eagly and Chaiken 2007). In the context of sustainability and wood products, previous studies reveal positive evaluations of and attitude towards LEED and EWPs among architects, but not necessarily LEED among clientele (USGBC 2019b; Ross, Woxblom, and McCluskey 2010). For example, research conducted on members of the Triangle Chapter of the USGBC in North Carolina show that barriers to sustainable design stem from a reluctance on the part of developers and investors to commit to the initial higher costs of sustainable design, regardless of cost saving features associated with the long-term operation of green building (Knowles et al. 2011). In the context of EWPs, Bysheim and Nyrud (2009) found architects' attitude towards wood as a structural material was a significant predictor of their intention to use wood in construction. These studies and other, stress the importance of understanding attitude towards certain characteristics of sustainable building design and EWPs as essential information for these sectors to be successful. For example, Gosselin et al. (2017) found architects had a positive attitude towards wood's characteristic, "ease of use"; in contrast, "fire resistance" was associated with a negative attitude.

\section{Experience and Familiarity}

Regular, direct experience can have a positive effect on intentions and subsequent behavior (Heberlein 2012). Similarly, familiarity is viewed as an important component of environmental sustainability preference (Hammitt 1979). A critical element of the LEED and EWPs context that is in line with this perspective is that few CLT structures exist in the United States, which limits opportunities for architects to gain first-hand experience and familiarity. Familiarity with CLT and other modern EWPs has been reported as low amongst architects across the United States. A 2015 study found that only $4.3 \%$ of responding architects were "very familiar" with CLT construction (Mallo and Espinoza 2015). Surveys of architectural firms indicated that $42.3 \%$ had learned of CLT through magazines and 20.3\% through the internet (Mallo and Espinoza 2015). Only 17.5\% gained primary information through professional conferences and workshops. As such, knowledge, experience, and familiarity regarding engineered wood products remains nascent among architects in the United States. (Mallo and Espinoza 2015). The research that does exist, on both LEED certification and EWPs, has largely been concentrated in regions outside the US South, such as the Pacific Northwest region. Aside from architects, general audiences also lack experience and familiarity with EWPs and expresses concern regarding both the safety of these structures in the event of fire and their environmental impacts (Larasatie et al. 2018; Gosselin et al. 2017). For example, when asked questions about their perceptions of wood use, general audiences tend to view wood construction as a contributor to deforestation. From this perspective, like architects, clients may have a varied attitudes, knowledge, and experience and familiarity with LEED and/or EWPs.

\section{Research Objectives}

A dearth of literature exists that examines the views of architects within localized US regions that have substantial forest resources and timber markets, like those in the southeastern United States. Arkansas, for example, maintains significant forest resources and timber industry interests but little is known of architects' perspectives on LEED and EWPs. In anticipation of emergent opportunities for sustainable building design initiatives with EWPs, there is a need to focus on architects within this region to better understand their perspective. Accordingly, this study poses the following research questions:

RQ1a. What level of familiarity/experience do Arkansas-based architects have with LEED certification?

RQ1b. To what extent do Arkansas-based architects perceive their clients to have familiarity/experience with LEED? 
RQ2. What are Arkansas-based architects' attitudes towards LEED and LEED sustainability goals in the context building design?

RQ3. What level of familiarity/experience do Arkansas-based architects have with EWPs?

RQ4a. What are Arkansas-based architects' attitudes towards the characteristics of EWPs, in comparison to steel/concrete?

RQ4b. What level of concerns with EWPs do Arkansas-based architects express?

\section{Study Context}

Structural wood use in the United States is highest in the western states and lowest in the south (Kozak and Cohen 1999). In Arkansas, to date, over 200 LEED certified buildings have been erected, but EWP use is minimal (USGBC 2019c). In 2019, the University of Arkansas' Fayetteville campus began construction of student dormitories that use prefabricated CLT panels imported from Europe (Black 2017). Other projects incorporating non-CLT wood products have been assembled within Arkansas to demonstrate the aesthetic value and cost-effectiveness of wood-framed construction. One example is El Dorado High School, which prominently features glue-laminated timber as both a structural and externally visible component. However, these few examples demonstrate the limited accessibility and high cost of projects incorporating CLTs. Yet, the southern US produces more than 50\% of the nation's construction lumber (Howard and Jones 2013). Over the last 40 years, forests in the U.S. South have been accumulating biomass at a rate of more than 2 billion cubic feet for year since 1963 (Wear and Greis 2012). This increase in forest biomass is an opportunity for economic development and alleviate environmental concern of forest overstocking, which can have deleterious effects on forest health.

\section{Data Collection}

To collect information from Arkansas-based architects, a questionnaire was developed that focused on sustainable building design, LEED certification and sustainability goals, and EWPs, including CLT. Question design followed previous studies that employed Likert-scales type items (Sutton 1998; Wastiels and Wouters 2012). Following an initial question formulation stage, a draft questionnaire was piloted and administered to four registered architects practicing in Arkansas to assess clarity and wording; results and feedback were incorporated into the final questionnaire. The final version of the questionnaire was approved by the University of Arkansas at Monticello Institution Review Board (FNR 1-185).

The study population was architects holding a membership with the Arkansas chapter of the American Institute of Architects (AIA). To reach this target group, we contacted organizational leadership to facilitate member participation. The resulting sample frame consisted of all active, registered AIA members $(n=589)$. The AIA distributed a questionnaire link via their electronic mailing list, with each recipient provided access to the questionnaire hosted by Qualtrics. Data collection occurred between June and August 2018. Following the initial invitation to participate, a reminder email was distributed to the sample approximately every two-weeks until no new responses were obtained. After data collection, data were cleaned in accordance with standard survey practices (Ruel, Wagner, and Gillespie 2015; Vaske 2008).

\section{Measures}

To assess what level of familiarity and experience Arkansas-based architects have with LEED certification, one Likert-scale type question asked, "Are you interested in LEED compliant building design?" ( 1 = yes, 2 = no, 3 = somewhat); and four questions asked, "What levels of LEED certification did you apply for [your building designs receive] before [after] 2014?" (1 = certified, 2 = silver, 3 = gold, 4 = platinum, 5 = none). To assess the extent to which Arkansas-based architects 
perceive their clients to have familiarity/experience with LEED, two questions asked, "Are your clients interested in LEED compliant building design" ( 1 =yes, 2 = no, 3 = somewhat); and "Have you developed LEED compliant building designs for a client" ( 1 = yes, 2 = no).

To gauge opinions on the seven sustainability goals derived from LEED v4 Impact Categories, participants were asked, "How important a consideration are these sustainability goals to you when designing a building?" ( 1 = not at all important, 5 = extremely important). The LEED v4 Impact Categories summarize intended outcomes of any LEED project. These goals include: "reverse contribution to global climate change", "enhance individual human health and well-being", "protect and restore water resources", "protect, enhance, and restore biodiversity and ecosystem services", "promote sustainable and regenerative material resources cycles", "build a greener economy", and "enhance social equity, environmental justice, and community quality of life" (Owens, Rohloff, and Rosenberg 2013). For the purposes of this questionnaire, the wording of these seven sustainability goals derived from these Impact Categories were modified to improve clarity and specificity (Table 2).

\begin{tabular}{c|l|l}
\hline 1 & \multicolumn{1}{|c}{ LEED v4 Impact Category } & \multicolumn{1}{|c}{ Sustainability Goal } \\
\hline 2 & Reverse Contribution to Global Climate Change & Mitigating Global climate change \\
\hline 3 & Protect and Restore Water Resources & $\begin{array}{l}\text { Protecting, conserving, and restoring water } \\
\text { resources }\end{array}$ \\
\hline 4 & $\begin{array}{l}\text { Protect, Enhance and Restore Biodiversity and } \\
\text { Ecosystem Services }\end{array}$ & $\begin{array}{l}\text { Protecting and restoring natural ecosystems and } \\
\text { biodiversity }\end{array}$ \\
\hline 6 & $\begin{array}{l}\text { Puild a Greener Econote Sustainable and Regenerative Material } \\
\text { Resource Cycles }\end{array}$ & $\begin{array}{l}\text { Increasing use of renewable/recyclable materials } \\
\text { to reduce environmental impacts }\end{array}$ \\
\hline 7 & $\begin{array}{l}\text { Enhance Social Equity, Environmental Justice, } \\
\text { Community Health and Quality of Life }\end{array}$ & $\begin{array}{l}\text { Building an economy that reduces environmental } \\
\text { risks and ecological scarcities }\end{array}$ \\
\hline
\end{tabular}

Next, to examine Arkansas-based architects' attitude towards LEED and LEED sustainability goals (derived from LEED v4 Impact Categories) in the context building design, one semantic differential scale questions asked, "Overall, how would you rate your experience(s) with the LEED certification system" ( 1 = extremely negative, 5 = extremely positive).

To assess levels of familiarity and experience with EWPs, two questions asked, "Prior to this survey, how familiar were you with these wood products?" ( $1=$ not at all, $5=$ a great deal) and "Have you used these wood products in your building designs?" ( 1 = yes, 2 = no). Attitude towards EWP was first assessed by asking participants, "How well do engineered wood products-like laminated beams and cross-laminated timber-perform in the face of natural forces in comparison to steel and concrete construction?" (1 = much worse, 5 = much better).

Next, participants were asked their opinion of EWP performance under select natural conditions (fire, earthquake, flooding, tornado, and seasonal climate cycles) compared to steel/concrete, i.e., "How important a consideration are these sustainability goals to you when you use engineered wood products (or considering using them) in your building design?" ( 1 = not at all important, $5=$ extremely important). Finally, to examine what level of concern Arkansas-based architects express towards EWPs factors (in terms of safety, durability, client acceptance, cost/price, assembly complication, aesthetic
Table 2

Comparison of LEED v4's Impact Categories and the sustainability goals in the questionnaire presented to Arkansas architects 
value, environmental impacts, availability/sourcing, and prestige), participants were asked, "To what extent do these considerations limit your use of engineered wood products in your building designs" ( 1 = not at all, $5=$ a great deal). The last section of the survey instrument asked standard sociodemographic questions.

\section{Analysis}

Standard descriptive statistics were generated for data exploration and initial summary of responses. Non-response bias was tested by using late responses as a proxy for non-respondents to test for non-response bias (Ruel, Wagner, and Gillespie 2015). T-tests were used to compare early- and late-responses for significant differences using $a=0.05$. The next stage of analysis involved a series of single factor analysis of variance (ANOVA). This allowed for comparisons to be drawn between categories for multi-faceted questions. With this, it was possible to determine whether significant differences existed between these categories. Mean scores were compared with a Tukey's test. A series of paired two-sample t-tests were also used to compare the sample means for architect and client interest in LEED and paired questions involving the seven LEED sustainability goals with regards to design only and design with engineered wood products.

In total, 88 responses were received for the questionnaire. However, four answer sets were discarded due to a lack of any response on questions. Out of the remaining 84 responses, 67 were entirely complete and 17 were partially complete. Using the American Association for Public Opinion Research (AAPOR) outcome rate calculator (AAPOR 2016), we calculated a response rate of 14.3\%. The average time on this questionnaire was 7 minutes and 26 seconds. Response rates of similar surveys of architects (Bysheim and Nyrud 2009; Wear and Greis 2012) were between 11.6 and 21.4 percent. In all 19 questions, no significant differences were found between early and late responders, inferring a lack of non-response bias. Of the respondents, $76.8 \%$ were male and $23.2 \%$ female. A majority of $89.7 \%$ self-identified as white. Black or African American respondents made up $2.9 \%$ of the sample group, and $7.6 \%$ identified their race as "other". Additionally, $55.7 \%$ of respondents stated they were not a member of the US Green Building Council, while $44.3 \%$ indicated that they were.

When asked to report the highest level of education attained, $75 \%$ of respondents indicated a bachelor's degree as their answer. A smaller percentage of $23.5 \%$ have received a master's degree, and $1.5 \%$ have graduate at the PhD level. Additionally, at $71 \%$, a large majority of respondents indicated that their highest educational degree was received at the University of Arkansas.

Results indicated that architects held some interest in LEED certification, with $67.9 \%$ affirming an interest in the program. They were also asked to evaluate the interests of their clients. Architects perceive that their clients possess less interest in LEED, with 59.5\% stating that their clients were only somewhat interested. A paired two-sample t-test revealed that architects reported significantly greater interest in LEED certification for themselves than what they feel their clients hold ("architects"; $\bar{x}=1.7, S=0.5 \ldots$ "clients"; $\bar{x}=1.0, S=0.6 \ldots$ "t-test"; $t(9.9) \ldots$ " p value"; $p<0.05$ ).

Within the sample group, $67.5 \%$ of architects affirmed they had previously developed LEED-compliant designs, while $32.5 \%$ had not. Amongst those respondents that had designed for LEED, $7.5 \%$ had not received certification prior to 2014, the year in which LEED v4 was introduced. Conversely, 27.5\% of respondents have not received LEED certification for any project developed after 2014.

Of those that applied prior to 2014 , a combined $38.3 \%$ received either the gold or platinum rating for a submitted design. For versions of LEED preceding $v 4$, only designs at these levels are considered substantially efficient in terms of energy use and renewability (Scofield 2013). Following 2014 and the introduction of $\mathrm{v} 4,23.6 \%$ of architects who had successfully applied for certification received the gold and platinum ratings. 


\begin{tabular}{c|c}
\hline Age & Respondents \\
\hline $18-24$ & 1 \\
\hline $25-35$ & 13 \\
\hline $36-44$ & 24 \\
\hline $45-54$ & 15 \\
\hline $55-64$ & 8 \\
\hline $65+$ & 8 \\
\hline Highest level of education & Respondents \\
\hline Bachelor's degree & 51 \\
\hline Master's degree & 16 \\
\hline PhD & 1 \\
\hline
\end{tabular}

\section{Table 3}

Reported demographic data of AIA Arkansas registered architects. Respondents reported on age and education level
In regards to the reported importance of sustainability goals in relation to building design, improving human health and well-being received the highest mean score, while mitigating global climate change ("improving human health and well-being"; $\bar{x}=4.4, \mathrm{SD}=0.7 \ldots$ "mitigating global climate change"; $\bar{x}=3.7, S D=1.2$ ) received the lowest. Based on 1-way ANOVA results, a significant difference was present amongst the mean scores. Results of the Tukey's means test indicate that the sustainability goal surrounding human health significantly differs from mitigating climate change and building an economy that reduces environmental risks and ecological scarcities (Fig. 1).

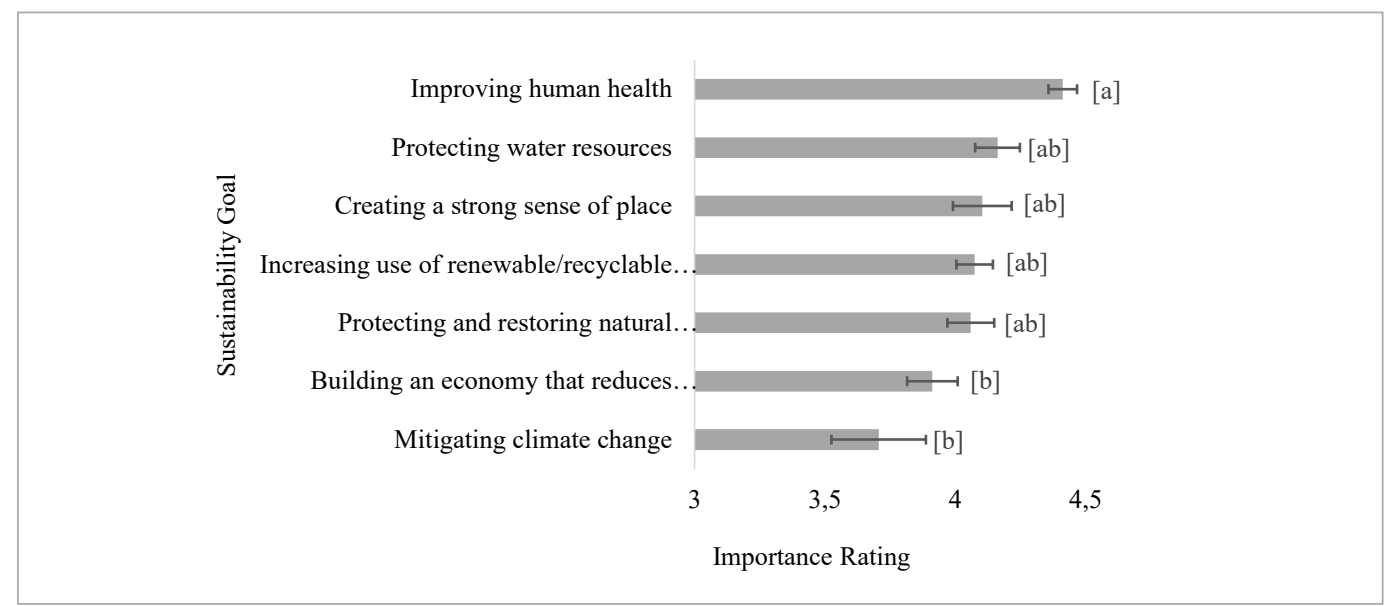

Error bars represent 1 standard error. Categories with different letter subscripts are significantly different $(a=0.05)$

When rating the importance of sustainability goals in relation to engineered wood product use, "increasing use of renewable/recyclable materials to reduce environmental impacts" received the highest score, while "mitigating global climate change" once again received the lowest score ("increasing use of renewable/recyclable materials"; $\bar{x}=3.9, \mathrm{SD}=0.8 \ldots$.. "mitigating global climate change"; $\bar{x}=3.3, S D=1.2$. ANOVA indicated a difference in the means, and Tukey's means difference test $(\mathrm{a}=0.05)$ determined that the score related to "renewable material use", "sense of place", and "improving human health and wellbeing" differed significantly from ratings assigned to "mitigating global climate change" (Fig. 2).
Fig. 1

Ranked mean importance of LEED derived sustainability goals by AIA architects in Arkansas in 2018 
Fig. 2

Ranked mean importance of sustainability goals as they relate to the use of engineered wood products by architects in Arkansas, 2018

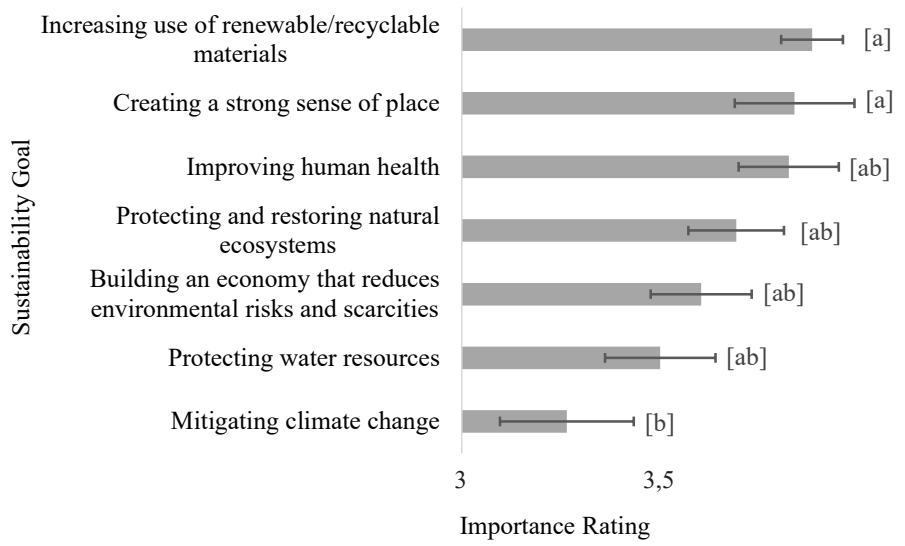

Black bars are used to indicate the standard error of each category. Categories with different letter subscripts are significantly different $(\alpha=0.05)$

Next, the mean importance ratings issued to each sustainability goal were compared between general building design and building design using engineered wood products. For these t-tests, significant differences were found to exist between all but one paired set of answers: 1) Mitigating global climate change $(p<0.05), 2)$ Improving human health and well-being $(p<0.05), 3)$ Protecting, conserving and restoring water resources $(p<0.05), 4)$ Protecting and restoring natural ecosystems and biodiversity $(p=0.00), 5)$ Increasing use of renewable/recyclable materials to reduce environmental impacts $(p=0.06)$, 6) Building an economy that reduces environmental risks and ecological scarcities $(p=0.01), 7)$ Creating a strong sense of place that is socially and environmentally inclusive $(p=0.01)$. No difference could be detected for the "increasing use of renewable/recyclable materials to reduce environmental impacts" goal. For every other goal category, mean importance ratings provided by architects were significantly lower when considering the use of engineered wood products (Table 4).

\footnotetext{
Table 4

Comparison of mean importance ratings of sustainability goals in relation to building design and the use of engineered wood products by architects in Arkansas
}

\begin{tabular}{l|c|c|c|c|c}
\hline \multirow{2}{*}{\multicolumn{1}{c}{ Sustainability Goal }} & \multicolumn{2}{c}{ Mean Importance Rating } & \multicolumn{2}{c}{ Standard Error } & P-Value \\
\cline { 2 - 6 } & Building Design & Wood Use & Building Design & Wood Use & \\
\hline Mitigating Global climate change & 3.71 & 3.26 & 0.181 & 0.169 & 0.0004 \\
\hline Improving human health and well-being & 4.41 & 3.82 & 0.055 & 0.126 & $<0.000$ \\
\hline $\begin{array}{l}\text { Protecting, conserving, and restoring } \\
\text { water resources }\end{array}$ & 4.16 & 3.50 & 0.085 & 0.139 & $<0.000$ \\
\hline $\begin{array}{l}\text { Protecting and restoring natural eco- } \\
\text { systems and biodiversity }\end{array}$ & 4.06 & 3.69 & 0.090 & 0.120 & 0.0028 \\
\hline $\begin{array}{l}\text { Increasing use of renewable/recyclable } \\
\text { materials to reduce environmental impacts }\end{array}$ & 4.07 & 3.88 & 0.070 & 0.078 & 0.0628 \\
\hline $\begin{array}{l}\text { Building an economy that reduces envi- } \\
\text { ronmental risks and ecological scarcities }\end{array}$ & 3.91 & 3.60 & 0.097 & 0.127 & 0.0156 \\
\hline $\begin{array}{l}\text { Creating a strong sense of place that is } \\
\text { socially and environmentally inclusive }\end{array}$ & 4.10 & 3.84 & 0.113 & 0.151 & 0.0132 \\
\hline
\end{tabular}

Mean ratings for each sustainability goal are provided under both the building design and wood use categories. P-values are provided to indicate significant differences between means 
Architects' familiarity with four specific engineered wood products: plywood panels, glue-laminated timber, cross-laminated timber (CLT), and dowel-laminated timber (DLT) is shown in Fig. 3. From 77 responses, it was concluded that architects hold a significantly greater familiarity with plywood panels and glue-laminated timber over CLT and DLT. Of all the products, DLT received the lowest score of familiarity ("plywood panels"; $x^{-}=4.2, \mathrm{SD}=0.9 \ldots$ "glue-laminated timber"; $x^{-}=4.1, \mathrm{SD}=0.9 \ldots$ "CLT"; $x^{-}=3.3, \mathrm{SD}=1.0 \ldots$ "DLT"; $\mathrm{x}^{-}=2.4, \mathrm{SD}=1.1 \ldots$ " $p$ value"; $\left.p<0.05\right)$.

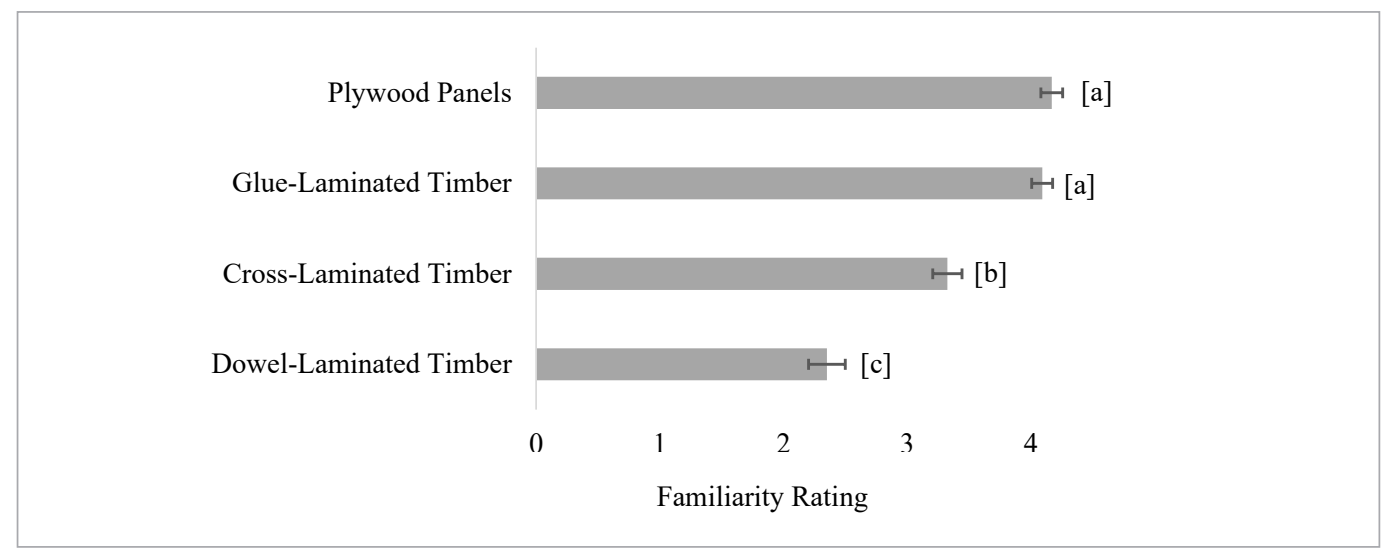

Black bars indicate standard error. Categories with different letter subscripts are significantly different $(\alpha=0.05)$

Architects have incorporated engineered wood products into their building designs. Out of the 77 respondents, $83.1 \%$ affirmed their use of plywood panels, while $89.6 \%$ had incorporated glue-laminated timber into a previous design. Mean usage rates for these two products did not differ significantly. CLT and DLT were reported to have been used by $20.8 \%$ and $7.8 \%$ of respondents, respectively. The use of CLT and DLT both differed from all other products and was found to be considerably lower than plywood panels or glue-laminated timber. DLT received the lowest use rating ("plywood panels"; $x^{-}=0.8, \mathrm{SD}=0.4 \ldots$ "glue-laminated timber"; $\mathrm{x}^{-}=0.9, \mathrm{SD}=$ $0.3 \ldots$ "CLT"; $x^{-}=0.21, \mathrm{SD}=0.4 \ldots$ "DLT"; $\mathrm{x}^{-}=0.08, \mathrm{SD}=0.3$ ) (Fig. 4).

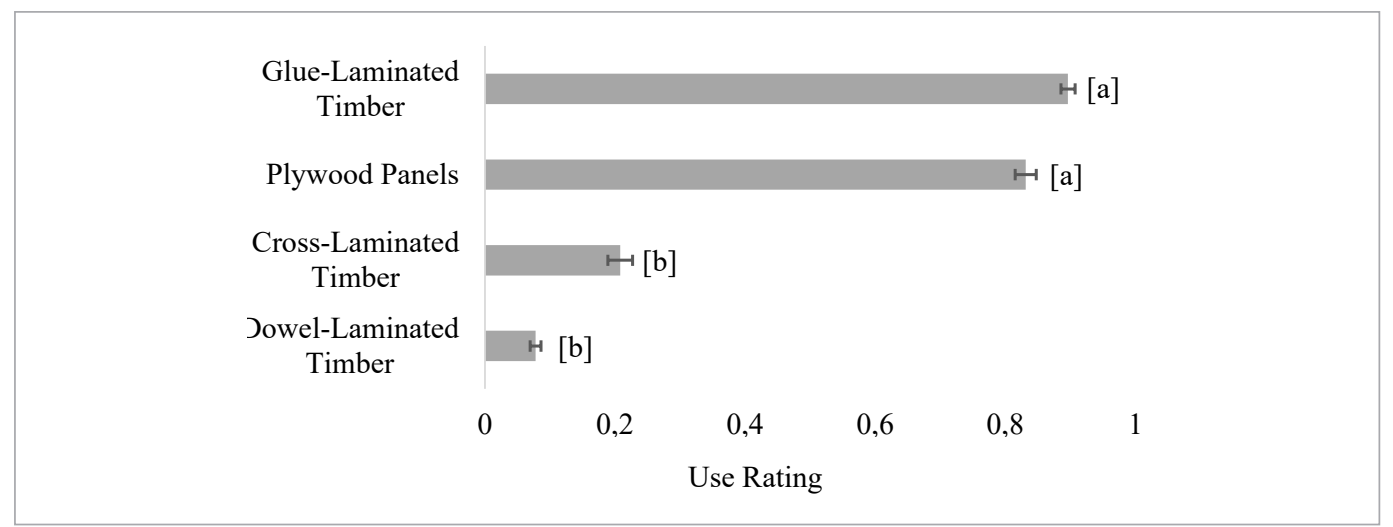

Black bars indicate standard error. Categories with different letter subscripts are significantly different $(\alpha=0.05)$

The limiting factors of greatest impact included cost/price, availability/sourcing, durability, and client acceptance. Cost/price and availability/sourcing were found to differ significantly from environmental impacts, safety, and prestige ("cost/price"; $\bar{x}=4.2, \mathrm{SD}=1.0 \ldots$ "availability/sourcing"; $\overline{\mathrm{x}}=3.9, \mathrm{SD}=1.1 \ldots$ "durability"; $\overline{\mathrm{x}}=3.8, \mathrm{SD}=1.0 \ldots$ "client acceptance"; $\overline{\mathrm{x}}=3.8, \mathrm{SD}=1.2 \ldots$ "assembly complication"; $\overline{\mathrm{x}}=3.6, \mathrm{SD}=1.1 \ldots$ "aesthetic value"; $\overline{\mathrm{x}}=3.6, \mathrm{SD}=1.2 \ldots$ "environmental impacts";
Fig. 3

Mean reported familiarity of engineered wood products amongst architects in Arkansas, 2018

Fig. 4

Mean usage of engineered wood products in architectural designs amongst architects in Arkansas, 2018 
$\overline{\mathrm{x}}=3.2, \mathrm{SD}=1.1 \ldots$ "safety"; $\overline{\mathrm{x}}=3.2, \mathrm{SD}=1.3 \ldots$ "prestige" $=\overline{\mathrm{x}}=2.0, \mathrm{SD}=1.2 \ldots$ "p value"; $p<0.05)$. The former categories were ranked as having the greatest ability to limit wood product use, while the latter factors were of lesser impact. Out of all factors, prestige was reported as having the lowest degree of impact, and significantly differed from all other categories (Fig. 5).

Seventy respondents supplied an answer to this question of EWP performance compared to steel and concrete. The mean scores were determined for fire, earthquake, flooding, tornado, and seasonal climate cycles ("fire"; $\bar{x}=0.2, S D=1.0 \ldots$ "earthquake"; $\bar{x}=0.5, S D=0.8 \ldots$ "flooding"; $\bar{x}=-0.5, S D=$ $0.9 \ldots$ "tornado" $=\bar{x}=-0.2, S D=0.9 \ldots$ "seasonal climate cycles"; $\bar{x}=0.1, S D=1.0 \ldots$ " $p$ value"; $p<0.05$ ).

Responses differed significantly from 0 for the performance of engineered wood products when exposed to earthquakes, fire, tornados, and flooding. No difference was detected for seasonal climate cycles. Engineered wood product performance under earthquake conditions was rated the highest, while flood performance received the lowest score. Based on ANOVA, the performance ratings for earthquake was significantly different from seasonal climate cycles, tornado, and flooding (Fig. 6).

Comparing responses regarding concerns and limitations associated with engineered wood actually and the stated use of those products allows and exploration of the real impact of those concerns. Flooding was the natural force most likely inhibit the wood use due to its low performance rating amongst architects (Fig. 6), and similarly concluded that cost/price was the limiting factor most likely to influence use (Fig. 5).

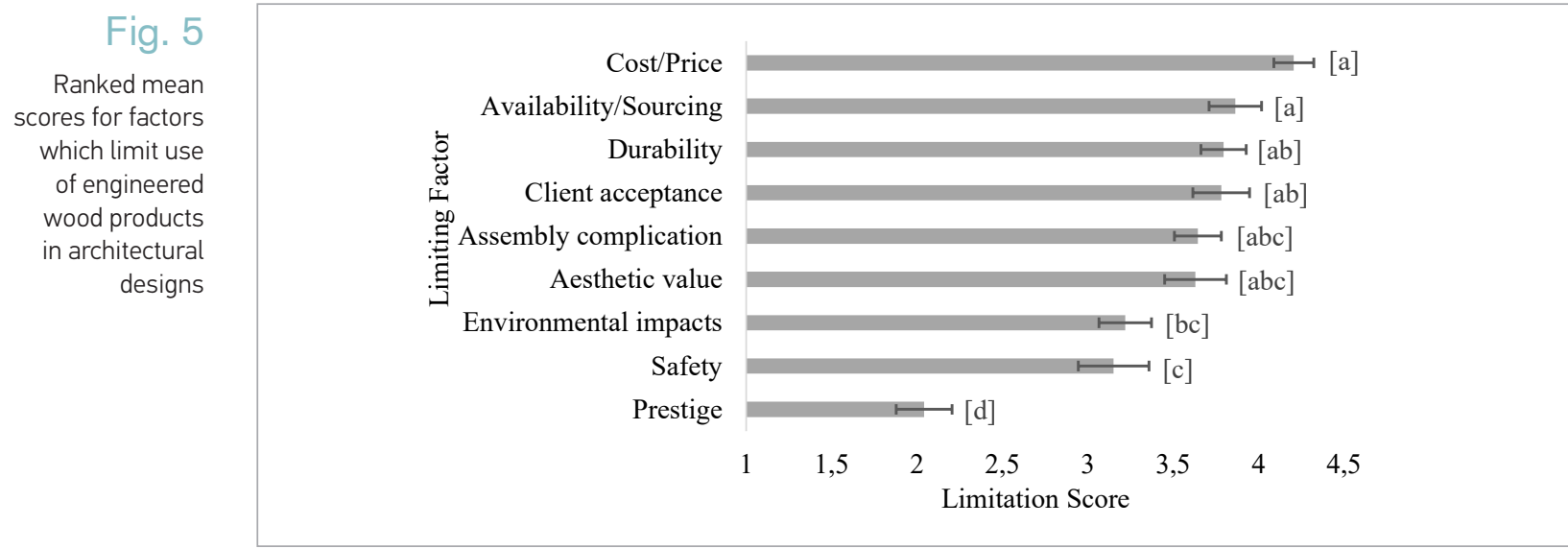

Black bars indicate standard error. Categories with different letter subscripts are significantly different $(\alpha=0.05)$

Fig. 6

Mean performance ratings of engineered wood products relative to steel and concrete construction by architects in Arkansas

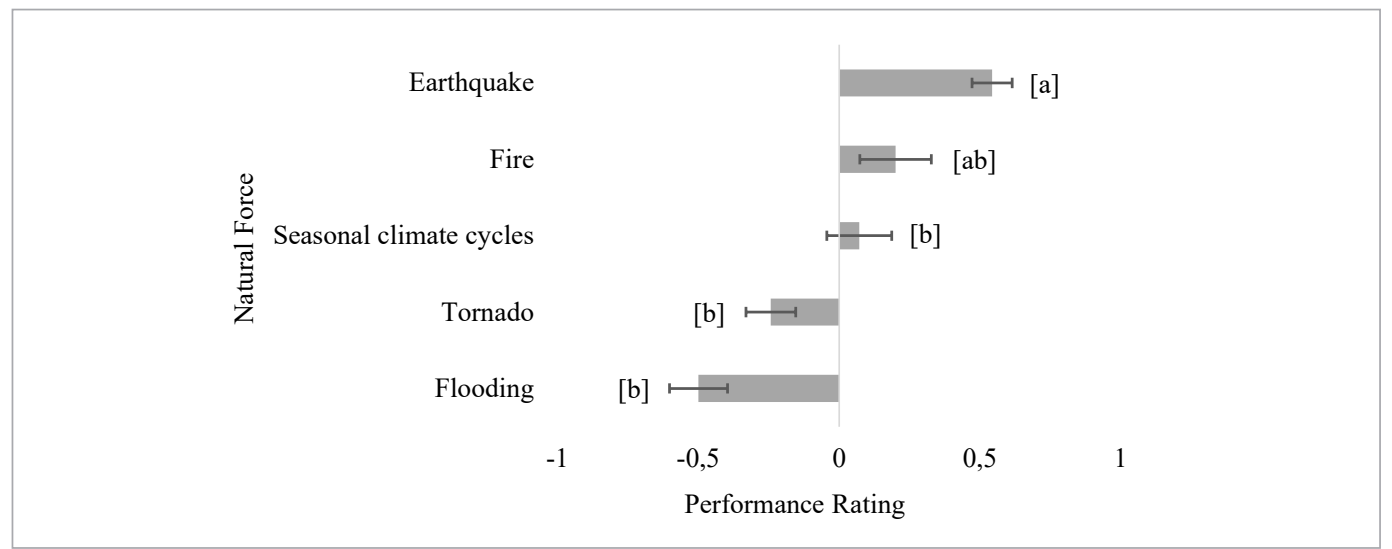

Black bars indicate standard error. Categories with different letter subscripts are significantly different $(\alpha=0.05)$ 


\section{Familiarity and Experience with LEED Certification?}

Respondents were largely both interested in and engaged with the LEED certification program, with roughly two thirds of respondents indicating prior participation. This suggests that concepts such as sustainable design and green building certification have already gained a degree of traction within the state of Arkansas. However, AIA Architects also believe that their clientele were significantly less interest in LEED certification than the architects themselves. This may represent a barrier to a more consistent and widespread application of the LEED program, as paying clients ultimately retain control over major design decisions. Architects, however, can serve as an essential component to promoting the benefits of green design and thus generate interest from their clients. Addressing the concerns and priorities held by architects interested in environmental design, especially in relation to engineered wood products can promote the recognition of EWPs as environmentally sustainable design elements.

\section{Attitude Towards LEED and Sustainability goals}

Out of the seven sustainability goals derived from the LEED v4's Impact Categories, improving human health and wellbeing was rated as being the most important. To promote LEED within the region, it will likely be necessary to emphasize the positive effects that green design has on factors such as the physical and mental health of occupants. To that end, previous research has uncovered a link between certified green buildings and improved respiratory health, as well as a reduction in self-reported stress and depression amongst occupants of LEED certified buildings (O'Connor et al. 2004).

In addition to improving human wellbeing, the sustainability goal of protecting water resources was also amongst those rated highly by respondents. With LEED v4's heightened focus on renewable material cycles and wood use, ecosystem benefits deriving from sustainable forest management, such as water quality improvement, could be presented to architects as a highlight of green building certification and sustainably produced CLT.

Respondents appear mindful of the environmental impacts associated with their designs, and thus it will be important to demonstrate the sustainable practices which contribute to CLT and other engineered wood products. It is understood that timber sequesters atmospheric carbon, while regular harvests allow newly regenerated forest stands to continue removing it through the processes of growth and respiration (Fell 2011) In one case, a cradle to gate life cycle analysis on glue-laminated timbers produced in the US Southeast showed that every cubic meter of glue-laminated material had a sequestered a net 1,083 kg of CO (Bergman and Bowe 2011).

Despite this, architects within Arkansas appear to believe that engineered wood products are less capable of promoting the sustainability goals of "protecting and restoring natural ecosystems and biodiversity" and "protecting, conserving, and restoring water resources". This may indicate that architects remained concerned about wood construction's contribution to deforestation and environmental degradation.

Architects may not be equally receptive to all facets of environmental protection and ecosystem restoration. One sustainability goal which did not rate especially high with Arkansas architects is "mitigating global climate change". This issue may not resonate as strongly with architects or their clientele within the target region, and thus demonstrations of LEED and CLT's carbon reduction potential may not serve to generate interest. Alternatively, it is possible that architects and their clients may not be aware how one building or one design can mitigate climate change, or how long-term sequestration of carbon in wood products as well as forests is a viable strategy for carbon sequestration, especially when carbon trading programs often do not grant carbon credits for increased use of wood.

\section{Familiarity and Experience with EWPs}

Architects tended to be most familiar with well-established and prolific examples of engineered wood products, which is intuitively sound. Plywood panels and glue-laminated timber are es- 
pecially popular design elements incorporated into a broad spectrum of architectural plans. No significant difference in familiarity was detected between these two products, with both having received the highest mean familiarity scores amongst the EWPs presented. On the other hand, CLT was a relatively lesser known material as compared to the aforementioned examples, which should not register as particularly unexpected given its slow adoption within the US. Unsurprisingly, actual use of newly developed EWPs such as CLT and DLT are significantly lower than that of plywood panels and glue-laminated timber.

\section{Attitude and Concern Towards EWPs}

Out of all potential limiting factor to EWPs within the state, cost, availability, duration and client acceptance rated the highest in terms of degree of impact. Previous research on the subject indicated that information barriers were amongst the chief limiters to EWP adoption but architects within this study region largely rate their knowledge of material as moderate to high, and thus cite other practical challenges as primary barriers (Ahn et al. 2013).

With costs being one of the greatest concerns, it should be noted that the cost competitiveness of a CLT will often be dependent on the specifications of the building itself and the region in which it is erected. In scenarios in which CLT is utilized, costs could be reduced when exposed wood is featured as an interior component (Woodworks 2012). Furthermore, reductions in construction time commonly associated with CLT structures would further contribute to cost savings (Woodworks 2012). In terms of availability and client acceptance, however, historically low demand within the region may impede adoption as opportunities to demonstrate the functional and aesthetic properties of new EWPs are lacking. Future projects cannot be expected to propagate without both the interest of property owners and the means to deliver

\section{Limitations and Future Research}

Of important note for this study is the possibility of bias in the respondent sample pool. As participation was entirely voluntary, it is possible that only architects especially interested in LEED or environmental sustainability elected to respond. Additionally, these results are only applicable to AIA members within Arkansas and may not be representative of all architects in the state. Despite these limitations, this study illustrates the impressions that even environmentally conscientious architects hold about engineered wood and LEED design, and thus study may serve as a valuable starting point for generating further interest amongst architects for these topics. Regarding the data collection of this study, there is potential for ambiguity due to the nonspecific language used in some questions. Asking architects to rate the importance of certain environmental goals may not be direct enough a question to ascertain what is truly meant by respondents. The issues related to wood use are complex, and other research as utilized a combination of qualitative and quantitative methods (O'Connor et al. 2004; Bysheim and Nyrud 2009) to identify, if not avoid, ambiguity in data.

We found that architects in Arkansas are generally knowledgeable and interested in LEED certification, but that their clientele are significantly less concerned with LEED standards. While all sustainability goals are moderately to strongly important to architects in the state, there are significant differences in this importance. Improving human health and well-being is significantly more important that building a green economy or mitigating climate change. Hemström and others (2017) obtained similar results from architects in Sweden. Arkansas and Swedish architects share similar importance on renewable/recyclable materials and construction costs

Arkansas architects expressed a belief that using EWPs are less capable than other materials in protecting water quality and restoring natural ecosystems. Yilmaz and Bakis (2015) found that intensive use of natural resources created the perception of negative environmental impacts from wood 
use. In the U.S. South, plantation forestry has converted nearly 16.5 million hectares of natural forest since 1950 (Wastiels and Wouters 2012). Certainly, this could lead to the perception that wood use is not particularly friendly to the environment and reduce the effort architects put into investigating wood use (Hemström, Mahapatra, and Gustavsson 2017; Mahapatra and Gustavsson 2008).

The use of emergent engineered wood products remains relatively low within the state of Arkansas although interest and participation in the green building certification program, LEED, appears to be quite high. Although the perception is that CLT performs comparably to steel and concrete construction, limited local manufacturing opportunities and increased cost incurrence, and inexperience with CLT design and construction are likely the most prominent factors limiting further product use. A potential solution may be to facilitate collaborative development, design, and construction (Gosselin et al. 2017). That is, sustainable design may have a higher probability of success when the forest and wood-products industry, developer and construction firms, and architects are incentivized to develop local collaborations in regions with the necessary private and public natural resources management infrastructure, like the southeastern US and eastern Arkansas.

\section{Acknowledgements}

Funding for this research was provided by the USDA Wood Innovations Grant.

Ahmed, M., Hasan, M.A., Mallick, J., World Green Building Rating System: A comparative study, International Conference Cum Exhibition on Building Utilities 2016, New Delhi, India: Department of Mechanical Engineering, Jamia Millia Islamia (2018) 1-3.

Ahn, Y.H., Pearce, A.R., Wang, Y., Wang, G., Drivers and barriers of sustainable design and construction: The perception of green building experience, International Journal of Sustainable Building Technology and Urban Development, 4 (1) (2013) 35-45. https:// doi.org/10.1080/2093761X.2012.759887

Ajzen, l., The theory of planned behavior. Organizational, Behavior and Human Decision Processes, 50 (1991) 179211.https://doi.org/10.1016/0749-5978(91)90020-T

Allport, G. W., Attitudes. In C. Murchison (Ed.), A handbook of social psychology, Worcester, MA: Clark University Press (1935) 798-844.

Amiri, A., Ottelin, J., Sovari, J., Are LEED-Certified Buildings Energy Efficient in Practice?, Sustainability, 11 (2019) 1672https://doi.org/10.3390/su1 1061672

Bergman, R.D., Bowe, S.A., Life-cycle inventory of manufacturing prefinished engineered wood flooring in the eastern United States, CORRIM Phase II Final Report. Module N. University of Washington, Seattle, WA, US. (2011) https://www.fs.usda.gov/treesearch/pubs/46319.

Black, L., The Stadium Drive Residence Halls at the University of Arkansas are under construction. St. Louis Post-Dispatch, (2017) https://www. stltoday.com/pr/business/the-stadium-drive-residence-halls-at-the-university-of-arkansas/article_ cce08354-d511-11e7-9493-5cb9017b8d1c.html.
Bysheim, K., Nyrud. A., Using a predictive model to analyze architects' intentions of using wood in urban construction, Forest Products Journal, 59 (7/8) (2009) 65-74.

Eagly,A.H.,Chaiken,S., Theadvantagesofaninclusivedefinition of attitude, Social cognition, 25 (5) (2007) 582-602. https://doi.org/10.1521/soco.2007.25.5.582

Fell, D.R., Wood in the human environment: Restorative properties of wood in the build indoor environment, Doctoral dissertation, University of British Columbia, Vancouver, CA (2011).

Franzini, F., Toivonen, R., Toppinen, A., Why not wood? Benefits and barriers of wood as a multistory construction material: Perceptions of municipal civil servants from Finland, Buildings, 8 (11) (2018) 159. https://doi.org/10.3390/buildings8110159

Gosselin, A., Blanchet, P., Lehoux, N., Cimon, Y., Main motivations and barriers for using wood in multi-story and non-residential construction projects, BioResources, 12 (1) (2017) 546-570.https:// doi.org/10.15376/biores. 12.1.546-570

Hammitt, W.E., Measuring familiarity for natural environments through visual images. in Proceedings of our national landscape: A conference on applied techniques for analysis and management of the visual resource, Incline Village, Nevada, Elsner, G.H., and R.C. Smardon (tech. coords.). USDA For. Serv., Gen. Tech. Rep. PSW-GTR-35. Pacific Southwest Forest and Range Experimental Station, Berkeley, CA. (1979) 217-226.

Heberlein, T. A., Navigating Environmental Attitudes, Oxford University Press, New York (2012). https://doi. org/10.1093/acprof:oso/9780199773329.001.0001

\section{References}


Hemström, K., Mahapatra, K., Gustavsson, L., Architects' perception of the innovativeness of the Swedish construction industry, Construction Innovation 17 (2) (2017), 17(2) 244-260 https://doi.org/10.1108/ Cl-06-2015-0038.

Howard, J.L., Jones, K.C. U.S. Timber Production, Trade, Consumption, and Price Statistics, USDA Forest Service Forest Products Laboratory Research Paper FPL-RP-679, 2016. (2013) 91.

Jain, M., Mital, M., Syal, M., Obstacles and Catalysts Associated with Implementation of LEED-EB ${ }^{\circledR}$ in India., Environment and Urbanization Asia, 4 (2) (2013) 349363.https://doi.org/10.1177/0975425313511164

Knowles, C., Theodoropoulos, C., Griffin, C., Allen, $J$., Oregon design professionals' views on structural building products in green buildings: implications for wood, Canadian journal of forest research, 41 (2) (2011) 390-400, https://doi.org/10.1139/X10-209

Kozak, R.A., Cohen, D.H., Architects and Structural Engineers: An examination of wood design and use in non-residential construction, Forest Products Journal, 49 (4) (1999) 37-46.

Larasatie, P., Guerrero, J.E., Conroy, K., Hall, T.E., Hansen, E., Needham M. D., What Does the Public Believe about Tall Wood Buildings? An Exploratory Study in the USPacific Northwest, Journal of Forestry, 116 (5) (2018) 429-436, https://academic.oup.com/jof/article-abstract/116/5/429/5078661 ?redirectedFrom=fulltext. https://doi.org/10.1093/jofore/fvy025

Mahapatra, K., Gustavsson, L., Multi-storey timber buildings: breaking industry path dependency, Building Research \& Information, 36 (6) (2008) 638-648. https://doi.org/10.1080/09613210802386123

Mallo, M. F. L., Espinoza O. A., Awareness, perceptions and willingness to adopt cross-laminated timber by the architecture community in the United States, Journal of Cleaner Production, 94 (2015) (2015) 198-210, https://www.sciencedirect.com/science/article/pii/ S0959652615001031.https://doi.org/10.1016/j.jclepro.2015.01.090

Matisoff, D. C., Noonan, D. S., Mazzolini A. M., Performance or marketing benefits? The case of LEED certification, Environmental science \& technology, 48 (3) (2014) 2001-2007,https://doi.org/10.1021/es4042447

Mat'ová, H., Kaputa, V., Attitudes of active and upcoming architects towards wood: The case study in Slovakia, Acta Facultatis Xylologiae Zvolen res Publica Slovaca, 60 (2) (2018) 199-209.

Newsham, G.R., Mancini, S., Birt, B.J., Do LEED certified buildings save energy? Yes, but..., Energy and Buildings, 41 (8) (2009) 897-905.https://doi. org/10.1016/j.enbuild.2009.03.014
O'Connor, J., Kozak, R., Gaston, C., Fell, D., Wood use in nonresidential buildings: Opportunities and Barriers, Forest Products Journal, 54 (3) (2004) 19-28.

Oku, H., Fukamachi, K., The differences in scenic perception of forest visitors through their attributes andrecreational activity, Landscape and urban planning 75 (1-2) (2006) 34-42.https://doi.org/10.1016/j. landurbplan.2004.10.008

Ortiz, O., Castells, F., Sonnemann, G., Sustainability in the construction industry: A review of recent developments based on LCA, Construction and building materials, 23 (1) (2009) 28-39, https://www.sciencedirect. com/science/article/abs/pii/S0950061807003005. https://doi.org/10.1016/j.conbuildmat.2007.11.012

Owens, B., Macken, C., Rohloff, A., Rosenberg, H., LEED v4 Impact category and point allocation process overview, US Green Building Council, (2013) https:// www.usgbc.org/resources/leed-v4-impact-category-and-point-allocation-process-overview.

Peterson, C., Vaske, J., Colorado Residents' Familiarity, Aesthetic Evaluations, and Approval of Forest Management Practices, Journal of Forestry, 115 (1) (2017) 10-15, https://doi.org/10.5849/jof.2016-029

Ritter, M.A., Skog K., Bergman, R., Science supporting the economic and environmental benefits of using wood and wood products in green building construction, U.S. Forest Service, Washington, DC, US, (2011) https://www.fs.usda.gov/treesearch/pubs/39927. https://doi.org/10.2737/FPL-GTR-206

Roos, A., Woxblom, L., McCluskey, D., The influence of architects and structural engineers on timber in construction-perceptions and roles, Silva Fennica, 44 (5) (2010) 871-884.https://doi.org/10.14214/sf.126

Ruel, E., Wagner III, W. E., Gillespie B. J., The practice of survey research: Theory and applications, Sage Publications. Los Angeles, CA, US, (2015).https:// doi.org/10.4135/978148339170

Scofield, J. H., Efficacy of LEED-certification in reducing energy consumption and greenhouse gas emission for large New York City office buildings, Energy and Buildings, 67 (2013) 517-524. https://www.sciencedirect.com/science/article/pii/S037877881300529X. https://doi.org/10.1016/j.enbuild.2013.08.032

Sutton, S., Predicting and explaining intentions and behavior: How well are we doing?, Journal of Applied Social Psychology 28 (15) (1998) 1317-1338.https:// doi.org/10.1111/j.1559-1816.1998.tb01679.x

The American Association for Public Opinion Research, Survey Outcome Rate Calculator 4.0, (2016).

UN International Energy Agency, Towards a zero-emission, efficient, and resilient buildings and construction sector, Global Status Report 2017, (2017), 
https://www.worldgbc.org/sites/default/files/ UNEP\%20188_GABC_en\%20\%28web\%29.pdf.

US Green Building Council, LEED v4 (2019a), https://new.usgbc.org/leed-v4.

US Green Building Council, LEED v4 building design + construction guide, (2019b), https://www.usgbc. org/guide/bdc\#rp_overview.

US Green Building Council, USGBC Arkansas (2019c), https://www.usgbc.org/usgbc-arkansas.

Van de Lindt, J.W., Pei, S., Pryor, S.T., Shimizu, H., Isoda, $H$., Experimental seismic response of a full-scale six-story light-frame wood building, Journal of Structural Engineering 136 (10) (2010) 1262-1272, https:// doi.org/10.1061/(ASCE)ST.1943-541X.0000222

Vaske, J. J. Survey research and analysis: Applications in parks, recreation and human dimensions. Venture Publishing. State College, PA, US. 2008.
Wastiels, L., Wouters, I., Architects' considerations while selecting materials. Materials and Design, 34 (2012), 584-593.https://doi.org/10.1016/j.matdes.2011.05.011

Wear, D.N., Greis, J.G., The Southern Forest Futures Project: Summary Report, USDA Forest Service Southern Research Station General Technical Report SRS-168, (2012) 68.

Woodworks, Cross laminated timber makes its mark with the Long Hall, WoodWorks (2012), https://www. woodworks.org/wp-content/uploads/CLT-Milestone-Montana.pdf.

Yilmaz, M, Bakis, A., Sustainability in the Construction Sector, Social and Behavioral Sciences, 19 (2015) 2253-2262.https://doi.org/10.1016/j.sbspro.2015.06.312

\section{GABRIELLE SHERMAN}

Program Technician

University of Arkansas at Monticello

College of Forestry, Agriculture \& Natural Resources

Main research area

Forest Resources.

\section{Address}

346 University Drive Monticello Ar, 71656 Tel. (412) 980-1818

E-mail: gabrielle.sherman@ maine.edu

\section{TAMARA WALKINGSTICK}

Associate Professor Associate Director for Extension

Arkansas Forest Resource Center

\section{Main research area}

Forest Resources.

\section{Address}

2301 S. University Ave. Little Rock, Ar 722044940

Tel. (501) 671-2000

E-mail: twalkingstick@uaex. edu

\section{KENNETH \\ WALLEN}

Assistant Professor

University of Arkansas

at Monticello

College of Forestry,

Agriculture \& Natural

Resources

Main research area

Forest Resources.

\section{Address}

P.O. Box 3468

110 University Ct. Monticello, AR 71655

Tel. (870) 460-1494

E-mail:

wallen@uamont.edu

\section{MATTHEW PELKKI}

Professor George H. Clippert Endowed Chair

University of Arkansas at Monticello College of Forestry, Agriculture \& Natural Resources.

\section{Main research area}

Forest Resources

\section{Address}

P.O. Box 3468

110 University Ct. Monticello, AR 71655

\section{About the Authors}

